\title{
MOLECULAR EVALUATION OF THREE POPULATIONS OF FARAFRA SHEEP IN COMPARISON TO OSSIMI AND RAHMANI SHEEP BREEDS
}

\author{
Talaat Bashandy ${ }^{1}$, Ahmed Hussein², Mohamed Solma³ ${ }^{3}$ Ayman Kassab³, \\ Hatem Hamdon ${ }^{3}$
}

${ }^{1}$ Department of Genetics, Faculty of Agriculture, New Valley University, New Valley, Egypt
${ }^{2}$ Department of Animal Production, Faculty of Agriculture, Assuit University, Asyut, Egypt
${ }^{3}$ Department of Animal Production, Faculty of Agriculture, New Valley University, New Valley, Egypt

Link to this article: https://doi.org/10.11118/actaun202068060929

Received: 20. 8. 2020, Accepted: 18. 11. 2020

To cite this article: BASHANDY TALAAT, HUSSEIN AHMED, SOLMA MOHAMED, KASSAB AYMAN, HAMDON HATEM. 2020. Molecular Evaluation of Three Populations of Farafra Sheep in Comparison to Ossimi and Rahmani Sheep Breeds. Acta Universitatis Agriculturae et Silviculturae Mendelianae Brunensis, 68(6): 929-936.

\begin{abstract}
Molecular markers are the most ideal approach to study genetic diversity. Consequently, we utilized both ISSR and RAPD markers to assess genetic diversity and relationships among three different populations of Farafra, Ossimi and Rahmani Egyptian sheep breeds. Both ISSR and RAPD gave moderate polymorphism $41.3 \%$ and $48.51 \%$, respectively. Besides, this value was consistent with the moderate value of the mean of polymorphism information content ( 0.16 and 0.20 , respectively). Farafra-F and Farafra-D populations had the highest similarity which was 0.92 for ISSR and 0.90 for the RAPD marker. Furthermore, ISSR and RAPD constructed dendrogram separated all the studied sheep into two main clusters. All the three populations of Farafra breed combined into one main cluster, while the second cluster contained both Rahmani and Ossimi breeds. The used molecular markers were able to discriminate among evaluated sheep and displayed that Farafra breed more closely related to Ossimi than Rahmani breed.
\end{abstract}

Keywords: dendrogram, Farafra sheep, genetic diversity, ISSR, molecular markers, RAPD

\section{INTRODUCTION}

Sheep are the most prevalent small ruminant in the world. It is one of the most important suppliers of animal protein, milk and wool. In Egypt, the total number of sheep is about 5,488,000. They are distributing almost all over the country regions (Elshazly and Youngs, 2019). They were classified into three major breeds, Rahmani, Ossimi and Barki. Additionally, eight minor breeds: Farafra, Saidi, Abidi, Abudeleik, Maenit, Kanzi, Sanabawi and Sohagi, which are located mainly in the southern part of the country and the oases (Elbeltagy, 2012). Ossimi sheep were found in Ossim village, Giza governorate. They having a white colour fleece, brown or dark brown head, semi pendulous ears and fat tail (weighing 2.5-4.0\% of the animal's body weight) and males have horns, while females do not have (Dehoux and Verhulst, 1994; Elshazly and Youngs, 2019). Concerning Rahmani sheep, resides in northern Syria and southern turkey. It was first introduced into Egypt in the 19 $9^{\text {th }}$ century in Rahmania in Beheira governorate, so the breed was named Rahmani. Rahmani sheep have reddish brown colour which fades with advancing age, small ears that are often vestigial, large tail weighing $4 \%$ of live weight and large horns in 
male but females are polled or have small horns (Dehoux and Verhulst, 1994; Elshazly and Youngs, 2019). On the other hand, among the minor breeds, Farafra is a native breed that dominates in Oases of El-Farafra, El-Dakhla and El-Kharga of the Egyptian Western Desert. It has a white fleece with a brown face, along cylindrical tail, males and females are typically polled and sometimes rams carry small size scurs on her body and carry small size ear (Elshazly and Youngs, 2019).

To assess a genetic variation within and between different sheep populations, numerous markers have been utilized. However, DNA molecular markers are the best tools, because they are not influenced by environmental alterations. Also, they are providing accurate information covering all genomic regions (Prasad et al., 2009). Among various PCR based molecular markers, Inter Simple Sequence Repeat (ISSR), and Randomly Amplified Polymorphic DNA (RAPD) have commonly been used in sheep (Elmaci et al., 2007; Mahfouz et al., 2008; Zamani et al., 2015; Mohammadabadi et al., 2017). ISSR is a dominant marker that can amplify DNA fragments between two simple sequence repeat regions without any prior sequence information (Zietkiewicz et al., 1994). Otherwise, RAPD is a simple and easy technique that uses single short primers usually 10 bases long to amplify random DNA fragments. Also, it does not need any information about the target sequence (Williams et al., 1990; Bardakci, 2001).

Indeed, Farafra sheep is adapted very well for the difficult desert environmental conditions, especially heat stress. Therefore, it is a good candidate could use in sheep genetic improvement programs. According to a literature survey, several papers concerning its morphological characterization (Mousa et al., 2006; Galal, 2007; Elbeltagy, 2012; Elshazly and Youngs, 2019). Moreover, only one available molecular study was performed by El-Hamamsy et al. (2018). They characterized three Egyptian sheep populations, collected from Siwa, El-Dakhla and El-Farafra Oases of the Egyptian Western Desert, using microsatellite marker and electrophoretic protein. Their study was performed on general sheep which lies in those regions and did not directed to Farafra sheep. Our study was the first investigation used two different DNA markers for assessing genetic diversity in Farafra breed and the relationship with other breeds.

The current study aims to evaluate genetic diversity and relationships within three different populations of Farafra breed and among all the studied sheep breeds using both the ISSR and RAPD molecular markers.

\section{MATERIALS AND METHODS}

Three populations of Farafra (from different locations of New Valley governorate, Egypt), Rahmani and Ossimi sheep breed were utilized in the current study (Tab. I).

\section{Blood Collection}

Two ml of whole blood were collected from the jugular vein of each animal, (50 individuals for each population of Farafra breed, 10 for each both Rahmani and Ossimi pure breeds) into $5 \mathrm{ml}$ vacutainer tubes containing EDTA (ethylenediaminetetraacetic acid) as ananticoagulant. The blood samples were stored at $-20{ }^{\circ} \mathrm{C}$ in the Genetics Department, Faculty of Agriculture, New Valley University. The experiment was carried out during November and December 2019.

\section{DNA Extraction}

The collected samples for each group were mixed to be one pooled sample per group. Genomic DNA was extracted from each pooled sample using animal DNA blood isolation kit (Wizard® Genomic DNA Purification) according to the manufacturer's instructions.

\section{PCR Amplification and Electrophoresis}

Both ISSR and RAPD PCR amplifications were performed in total reaction mixture volume of $25 \mu \mathrm{l}$ containing: $12.5 \mu \mathrm{l}$ of green PCR Master Mix, 2X (50 units/ml Taq DNA polymerase, $400 \mu \mathrm{M}$ of each dATP, dGTP, dCTP and dTTP and $3 \mathrm{mM} \mathrm{MgCl}_{2}$ ), $2 \mu \mathrm{l}$ of $10 \mu \mathrm{M}$ primer, $2 \mu \mathrm{l}$ of DNA (50 ng) and $8.5 \mu \mathrm{l}$ of $\mathrm{ddH}_{2} \mathrm{O}$. Amplifications were performed in a thermal

I: The name, original place and morphological characteristics of the studied sheep

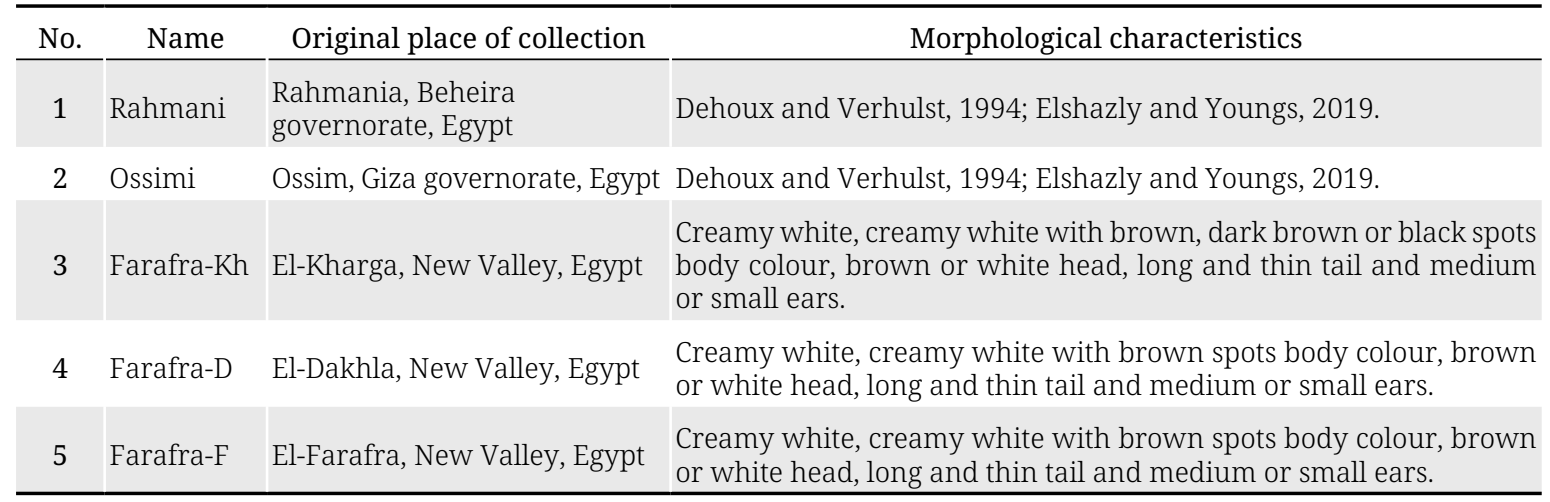


II: Primer ID and sequences of both ISSR and RAPD

\begin{tabular}{lccc}
\hline ISSR Primers & $\begin{array}{c}\text { Sequence } \\
\text { (5' to 3 } \text { ( }^{\prime}\end{array}$ & $\begin{array}{c}\text { RAPD } \\
\text { Primers }\end{array}$ & $\begin{array}{c}\text { Sequence } \\
\text { (5' to } 3^{\prime} \text { ) }\end{array}$ \\
\hline UBC 807 & (AG)8T & OPB12 & CCTTGACGCA \\
UBC 808 & (AG)8C & OPF04 & GGTGATCAGG \\
UBC 810 & (GA)8T & OPC11 & AAAGCTGCGG \\
UBC 811 & (GA)8C & OPC14 & TGCGTGCTTG \\
UBC 812 & (GA)8A & OPD08 & GTGTGCCCCA \\
UBC 814 & (CT)8A & OPD18 & GAGAGCCAAC \\
UBC 815 & (CT)8G & OPL05 & ACGCAGGCAC \\
UBC 818 & (CA)8G & OPW06 & AGGCCCGATG \\
UBC 823 & (TC)8C & S11 & GTAGACCCGT \\
UBC 826 & (AC)8C & UBC751 & CCCACCACAC \\
UBC 834 & (AG)8TT & & \\
UBC 840 & (GA)8TT & & \\
\hline
\end{tabular}

cycler (Labocon, U.K.). Twelve ISSR primers and ten RAPD primers were used (by metabion; Tab. II). The PCR amplifications program starting with initial denaturation at $94^{\circ} \mathrm{C}$ for $5 \mathrm{~min}$ then, followed by 38 cycles: denaturation at $94^{\circ} \mathrm{C}$ for $1 \mathrm{~min}$, annealing at $48^{\circ} \mathrm{C}$ for ISSR or at $35^{\circ} \mathrm{C}$ for RAPD primers for $1 \mathrm{~min}$, extension at $72^{\circ} \mathrm{C}$ for $2 \mathrm{~min}$, with a final extension at $72^{\circ} \mathrm{C}$ for $7 \mathrm{~min}$. PCR products were separated on $1.5 \%$ agarose gels using $1 \times \mathrm{TBE}$ (Tris-Borate-EDTA) running buffer at $5 \mathrm{~V} / \mathrm{cm}$. Then, they were visualized by staining with ethidium bromide.

\section{Data Analysis}

We recorded 1 for the present bands and 0 for absent band. Genetic similarity was estimated using Jaccard's similarity coefficient (Jaccard, 1908). A dendrogram was constructed using unweighted pair group method with arithmetic average (UPGMA) based on the similarity matrix data, cluster analysis and Shannon's Information index (I) were calculated using the software computational package MVSP 3.1. program. Different indices namely, polymorphic information contents (PIC), resolving power (Rp) and marker index (MI) were calculated according to Anderson et al. (1993); Prevost and Wilkinson (1999); Powell et al. (1996), respectively.

\section{RESULTS AND DISCUSSION}

\section{A- Polymorphism Assessment}

To study the genetic distance among the three populations of Farafra, Rahmani and Ossimi breeds, twelve ISSR and ten RAPD molecular markers were used (Figs. 1 and 2, respectively). About the ISSR marker, a total of 92 bands were scored with size varied from $200 \mathrm{bp}$ to $1344 \mathrm{bp}$. Only 38 bands were polymorphic, with $41.3 \%$ polymorphism
(Tab. III). On the other hand, RAPD markers detected 101 bands having size ranged from $178 \mathrm{bp}$ to 1910 bp, 49 bands among them were polymorphic. However, the estimated polymorphism was 48.51\% (Tab. III). ISSR and RAPD molecular markers have been widely used in the detection of genetic diversity in sheep (Elmaci et al., 2007; Mahfouz et al., 2008; Zamani et al., 2015; Mohammadabadi et al., 2017). The ISSR marker detected moderate polymorphism percentage (41.3\%) close to but less than which detected by RAPD molecular marker (48.51\%). Reflecting, the RAPD marker is more effective in the detection of molecular polymorphism. This may be due to the RAPD is less specific than ISSR and screens all most the genome. This result is similar to the findings of Guasmi et al. (2012), Haider et al. (2012), Elmeer et al. (2017). Moreover, to study further the capacity of the markers for detecting polymorphism, so the PIC value was estimated. In ISSR this value ranged from 0.06 to 0.32 with an average of 0.16 , while in RAPD marker varied from 0.06 to 0.35 with an average of 0.20 . Actually, the RAPD marker exhibited a higher level of PIC average, as it also reported by Guasmi et al. (2012), Elmeer et al. (2017). The PIC average values of both ISSR and RAPD were moderate, thus showed moderate detectable polymorphism. Additionally, the primer resolving power (Rp) was calculated to determine the preferable primers in each marker. The $\mathrm{Rp}$ for ISSR primers fluctuated from 0.4 for both UBC 810 and UBC 823 primer to 5.6 for UBC 834 primer, while this value varied from 0.8 to 5.2 for OPD18 and OPC11, respectively. Moreover, to evaluate the efficiency of the two markers for the detection of variations, the marker index (MI) was calculated. The results showed that the MI value was higher in RAPD (1.12) than ISSR (0.67). Thus, the RAPD had more effectiveness in comparison to the ISSR marker. Furthermore, Shannon's information index was used for further detection of genetic diversity among all the breeds. Among the used ISSR primers, UBC 834 displayed the highest value (2.51), but UBC 823 had the least value (0.18) with an average of 0.89 . On the other hand, in RAPD marker ranged from 0.37 to 2.53 for OPD18 and OPC11, respectively, with an average of 1.38. Shannon index value for both ISSR and RAPD markers revealed low genetic diversity among all studied sheep this may be due to high inbreeding mating in those studied populations. Almost all the previous indices were higher in RAPD than in the ISSR marker this finding is in agreement with several studies (Guasmi et al., 2012; Tonk et al., 2014; Elmeer et al., 2017).

\section{B- Genetic Similarly and Relationship}

To study the level of genetic relationship among all the studied sheep, the level of similarity among them was estimated by using Jaccard's similarity coefficient depending on ISSR and RAPD data (Tab. IV). Both of ISSR and RAPD markers showed the highest similarity (0.92 and 0.90 , respectively) 


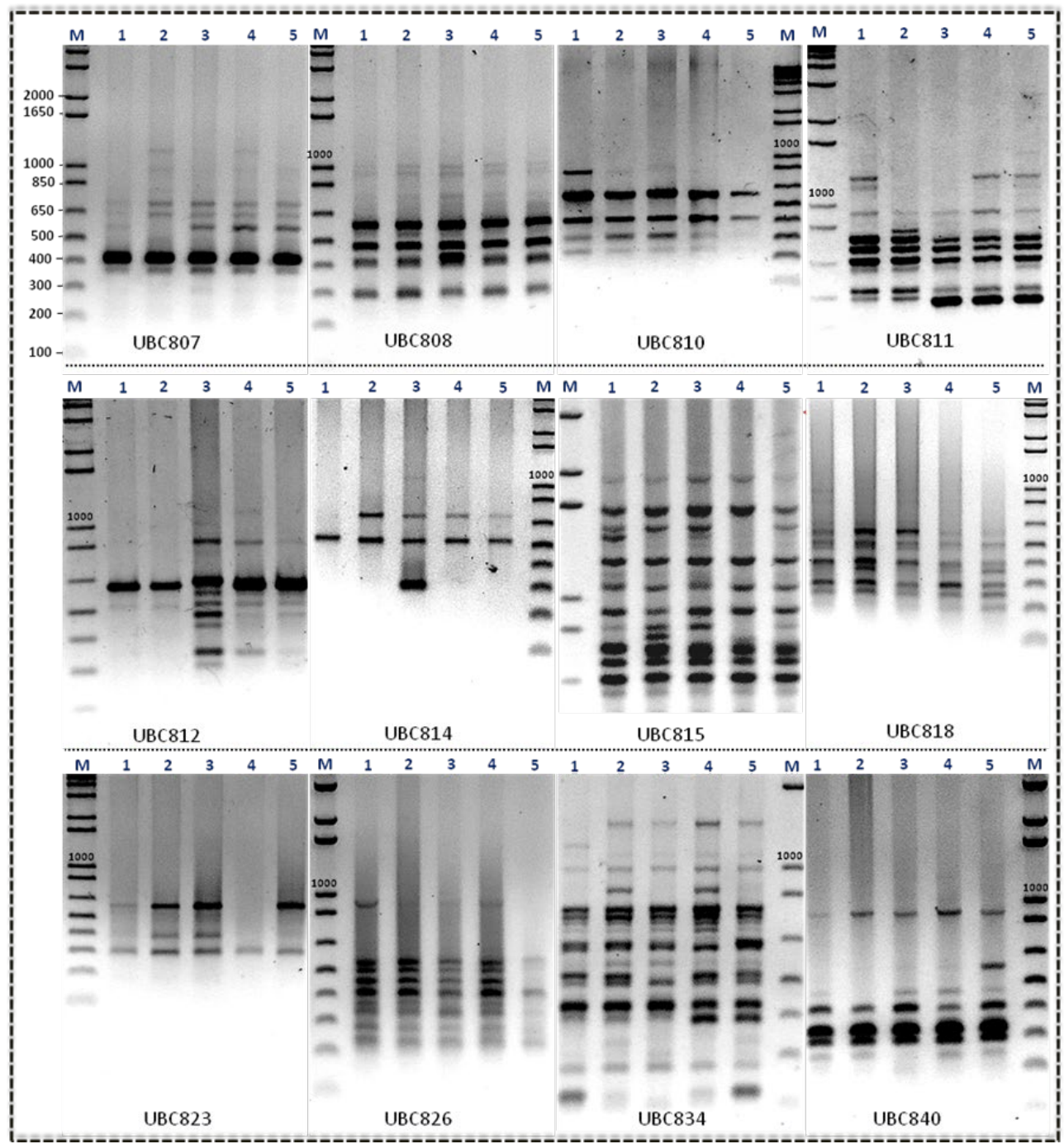

1: ISSR banding pattern of the studied sheep. 1, Rahmani; 2, Ossimi; 3, Farafra-Kh; 4, Farafra-D; 5, Farafra-F. M, kbp DNA marker

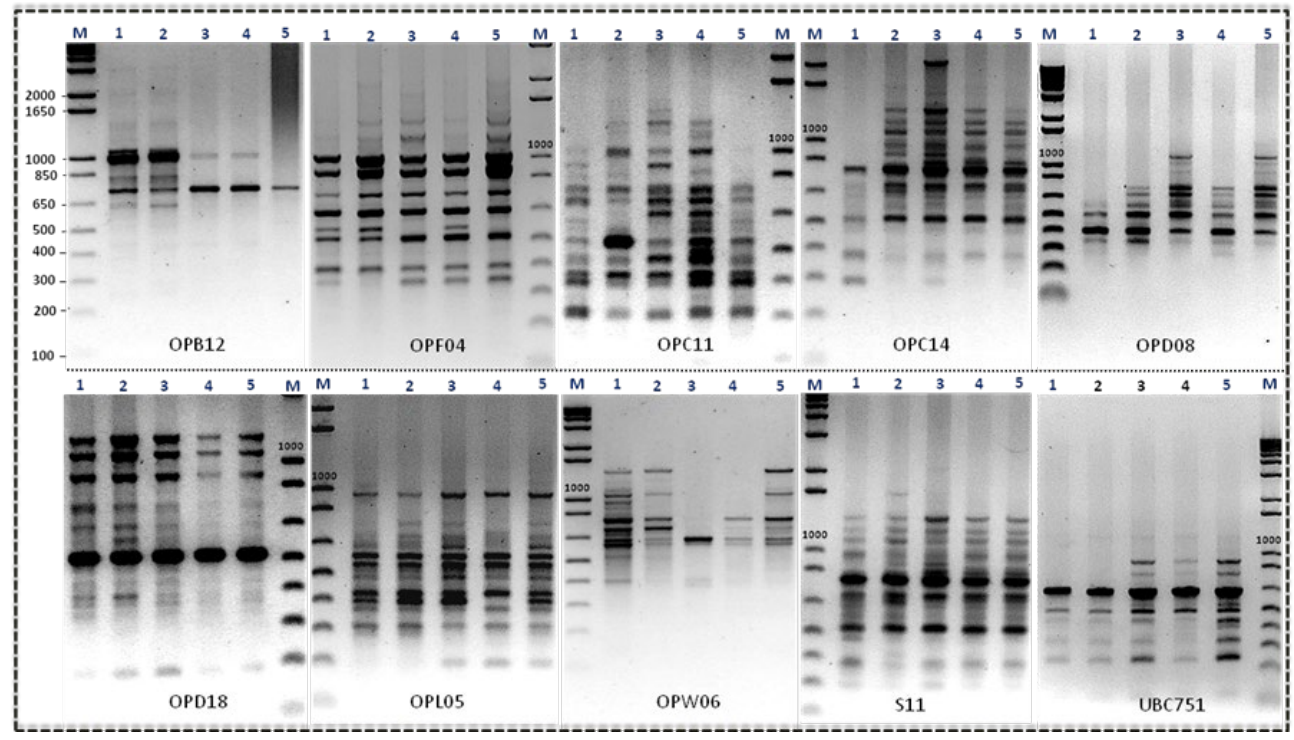

2: RAPD banding pattern of the studied sheep. 1, Rahmani; 2, Ossimi; 3, Farafra-Kh; 4, Farafra-D; 5, Farafra-F. M, kbp DNA marker 
III: Polymorphism, Polymorphism Information Content, Marker index, Resolving power and Shannon's index values obtained by ISSR and RAPD markers in the studied sheep

\begin{tabular}{|c|c|c|c|c|c|c|c|c|c|}
\hline Primer Name & $\begin{array}{l}\text { Range of fragment } \\
\text { size bp }\end{array}$ & $\begin{array}{c}\text { Total } \\
\text { No. of fragments }\end{array}$ & $\begin{array}{c}\text { Monomorphic } \\
\text { fragments }\end{array}$ & $\begin{array}{c}\text { Polymorphic } \\
\text { fragments }\end{array}$ & P \% & PIC & MI & $\mathrm{Rp}$ & I \\
\hline \multicolumn{10}{|c|}{ ISSR } \\
\hline UBC 807 & 365-1155 & 7 & 4 & 3 & 42.86 & 0.18 & 0.55 & 2 & 0.79 \\
\hline UBC 808 & 295-1000 & 7 & 6 & 1 & 14.3 & 0.07 & 0.07 & 0.8 & 0.37 \\
\hline UBC 810 & 205-785 & 5 & 4 & 1 & 20 & 0.06 & 0.06 & 0.4 & 0.32 \\
\hline UBC 811 & 490-1344 & 10 & 6 & 4 & 40 & 0.16 & 0.64 & 2.4 & 1.26 \\
\hline UBC 812 & $320-890$ & 8 & 2 & 6 & 75 & 0.32 & 1.92 & 4 & 1.87 \\
\hline UBC 814 & $310-710$ & 3 & 1 & 2 & 66.67 & 0.21 & 0.42 & 0.8 & 0.5 \\
\hline UBC 815 & $380-987$ & 13 & 8 & 5 & 38.46 & 0.14 & 0.70 & 2.4 & 1.16 \\
\hline UBC 818 & $200-575$ & 8 & 5 & 3 & 37.5 & 0.16 & 0.48 & 2.0 & 0.85 \\
\hline UBC 823 & $300-575$ & 3 & 2 & 1 & 33.33 & 0.11 & 0.01 & 0.4 & 0.18 \\
\hline UBC 826 & 224-950 & 8 & 7 & 1 & 12.5 & 0.06 & 0.6 & 0.8 & 0.37 \\
\hline UBC 834 & 230-1330 & 14 & 5 & 9 & 64.29 & 0.26 & 2.34 & 5.6 & 2.51 \\
\hline UBC 840 & $265-860$ & 6 & 4 & 2 & 33.33 & 0.13 & 0.26 & 1.2 & 0.49 \\
\hline Total & - & 92 & 54 & 38 & - & - & - & - & 9.62 \\
\hline Average & - & 7.67 & 4.5 & 3.17 & 40.57 & 0.16 & 0.67 & - & 0.89 \\
\hline \multicolumn{10}{|c|}{ RAPD } \\
\hline OPB12 & 640-1080 & 5 & 1 & 4 & 80 & 0.35 & 1.4 & 2.8 & 1.28 \\
\hline OPF04 & $325-1000$ & 8 & 6 & 2 & 25 & 0.1 & 0.2 & 1.2 & 0.49 \\
\hline OPC11 & 340-1335 & 15 & 6 & 9 & 60 & 0.24 & 2.16 & 5.2 & 2.53 \\
\hline OPC14 & 290-1910 & 12 & 3 & 9 & 75 & 0.27 & 2.43 & 4.4 & 2.21 \\
\hline OPD08 & $325-1125$ & 10 & 4 & 6 & 60 & 0.24 & 1.44 & 3.6 & 1.52 \\
\hline OPD18 & $360-1160$ & 8 & 7 & 1 & 12.5 & 0.06 & 0.06 & 0.8 & 0.37 \\
\hline OPL05 & 178-960 & 13 & 7 & 6 & 46.15 & 0.19 & 1.14 & 3.6 & 1.52 \\
\hline OPW06 & $380-1456$ & 11 & 5 & 6 & 54.55 & 0.25 & 1.5 & 4.4 & 2.03 \\
\hline S11 & 368-1295 & 11 & 8 & 3 & 27.27 & 0.1 & 0.3 & 1.6 & 0.95 \\
\hline UBC751 & 240-915 & 8 & 5 & 3 & 37.5 & 0.18 & 0.54 & 2.4 & 0.92 \\
\hline Total & - & 101 & 52 & 49 & - & - & - & - & 13.82 \\
\hline Average & - & 10.1 & 5.2 & 4.9 & 47.80 & 0.20 & 1.12 & - & 1.38 \\
\hline
\end{tabular}

$\mathrm{P}$ = Polymorphism, MI = Marker index, $\mathrm{PR}=$ Resolving power, $\mathrm{I}$ = Shannon's Information index

between Farafra-F and Farafra-D populations. Also, they revealed the lowest similarity (0.69 and 0.60, respectively) between Rahmani breed and Farafra-D population. Moreover, the dendrogram of genetic distance in both ISSR and RAPD markers classified all the studied sheep into two main clusters (Fig. 3). the first one contained all the three populations of Farafra breed and divided into two sub-clusters, one of them grouped both Farafra-F and Farafra-D populations, while the second one contained only Farafra-Kh population. On the other hand, the second cluster gathered both Rahmani and Ossimi breeds. Furthermore, the results of combined ISSR and RAPD data also showed that the highest similarity (0.91) was between Farafra and Eldakhla populations. Ossimi breed and Dakhla population had the lowest similarity (0.64). Additionally, the combined data conducted the same dendrogram as in individual ISSR or RAPD marker. The higher similarity between Farafra-F and Farafra-D and grouping them in the same sub-cluster indicated that they have higher homozygosity than Farafra-Kh (Mahfouz et al., 2008). This higher similarity is maybe due to more exchange in animal trade and in all aspects of life between El-Farafra and El-Dakhla region. Furthermore, there are many common and relative human families between them more than El-Kharga. Additionally, they are more isolated geographical regions in comparison to El-Kharga. Moreover, all the three groups of Farafra breed were more closely related to Ossimi than the Rahmani breed, this is fitted with that Farafra 
IV: The similarity index among the studied sheep based on ISSR, RAPD and combined analysis

\begin{tabular}{|c|c|c|c|c|c|}
\hline Genotypes & Rahmani & Ossimi & Farafra-Kh & Farafra-D & Marker type \\
\hline \multirow{3}{*}{ Ossimi } & 0.78 & & & & ISSR \\
\hline & 0.76 & & & & RAPD \\
\hline & 0.77 & & & & Comined \\
\hline \multirow{3}{*}{ Farafra-Kh } & 0.73 & 0.73 & & & ISSR \\
\hline & 0.61 & 0.68 & & & RAPD \\
\hline & 0.66 & 0.71 & & & Comined \\
\hline \multirow{3}{*}{ Farafra-D } & 0.69 & 0.76 & 0.84 & & ISSR \\
\hline & 0.60 & 0.69 & 0.86 & & RAPD \\
\hline & 0.64 & 0.72 & 0.85 & & Comined \\
\hline \multirow{3}{*}{ Farafra-F } & 0.74 & 0.76 & 0.89 & 0.92 & ISSR \\
\hline & 0.62 & 0.72 & 0.89 & 0.90 & RAPD \\
\hline & 0.67 & 0.74 & 0.89 & 0.91 & Comined \\
\hline
\end{tabular}

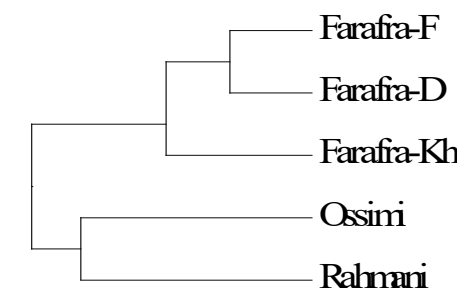

$\begin{array}{llllllll}0.7 & 0.75 & 0.8 & 0.85 & 0.9 & 0.95 & 1\end{array}$

A) ISSR

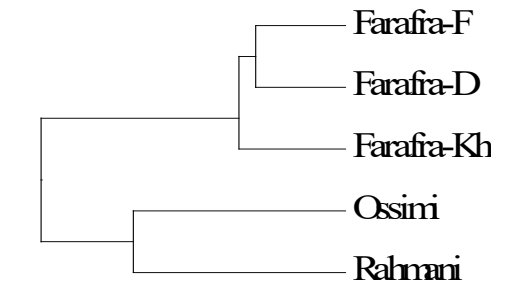

$\begin{array}{lllllll}0.64 & 0.7 & 0.76 & 0.82 & 0.88 & 0.94 & 1\end{array}$

B) RAPD

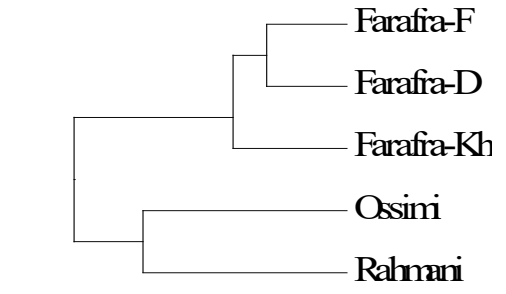

$0.640 .7 \quad 0.760 .82 \quad 0.880 .94$

C) Combined

3: The dendrograms of genetic distances among the studied sheep based on ISSR, RAPD marker and combined analysis

breed may be resulted from crossing between Ossimi and any desert breed (Elshazly and Youngs, 2019). On the other hand, Ossimi and Rahmani breeds were located in one main cluster this result is in agreement with the findings of Mahfouz et al. (2008); Othman et al. (2015). The detected identity between them in the RAPD marker was less than which was obtained by Mahfouz et al. (2008); Abdel-rahman et al. (2010) (0.975 and 0.87, respectively). The closeness of Ossimi and Rahmani has been confirmed by using many different types of DNA molecular markers (Abdel-rahman et al., 2010; Ghazy et al., 2013; Othman et al., 2015; Rushdi, 2018). Actually, Rahmani and Ossimi breeds are distributed in close geographical locations this leads to intermixing of genetic material between them. Obviously, the resulted data from both ISSR and RAPD markers are more consistent with their geographic distribution and genetic makeup. The current study could provide further helpful information about genetic diversity within Farafra breed and the level of relatedness with other breeds located in different close geographical regions around.

\section{CONCLUSION}

The present study aimed to evaluate genetic diversity and the relationship among three different populations of Farafra breed, in addition to two pure breeds (Rahmani and Ossimi). Moderate value for both of polymorphism and genetic diversity were observed among the studied sheep. The three populations of Farafra have the most closeness. Furthermore, these populations had higher similarity and closer proximity to Ossimi more than to Rahmani breed. The study provided further information regarding Farafra breed.

\section{Acknowledgements}

We are grateful to the Faculty of Agriculture, New Valley University, Egypt for the financial support of this work. 


\section{REFERENCES}

ABDEL-RAHMAN, S. M., EL-NAHAS, A. F., HEMEDA, S. A., EL-FIKY, S. A. and NASR, S. M. 2010. Genetic variability among four Egyptian sheep breeds using random amplified polymorphic DNA (RAPD) and PCR-RFLP Techniques. Journal of Applied Sciences Research, 6(1): 1-5.

ANDERSON, J., CHURCHILL, G., AUTRIQUE, J., TANKSLEY, S. and SORRELLS, M. 1993. Optimizing parental selection for genetic linkage maps. Genome, 36(1): 181-186.

BARDAKCI, F. 2001. Random amplified polymorphic DNA (RAPD) markers. Turkish Journal of Biology, 25: 185-196.

DEHOUX, J. and VERHULST, A. 1994. Une race trypanotolerante méconnue: la Borgou. Animal Genetic Resources/Resources génétiques animales/Recursos genéticos animales, 13: 39-45.

ELBELTAGY, A. R. 2012. Characterization and value addition to local breeds and their products in the Near East and North Africa. In: Regional Workshop Rabat, Morocco. 19-21 November.

EL-HAMAMSY, S., EL-SAYED, M., EL BADAWY, A. and TELEB, D. 2018. Characterization of some Egyptian sheep populations using microsatellite and protein markers. Journal of Agricultural Chemistry and Biotechnology, 9(8): 181-188.

ELMACI, C., ONER, Y., OZIS, S. and TUNCEL, E. 2007. RAPD analysis of DNA polymorphism in Turkish sheep breeds. Biochemical genetics, 45(9-10): 691-696.

ELMEER, K., ALGHANEM, M., AL-LATIFI, L. and ALHEMAIRI, H. 2017. Efficiency of RAPD and ISSR markers for the detection of polymorphisms and genetic relationships in date palm. Biotechnology, 16(1): 19-26.

ELSHAZLY, A. G. and YOUNGS, C. R. 2019. Feasibility of utilizing advanced reproductive technologies for sheep breeding in Egypt. Part 1. Genetic and nutritional resources. Egyptian Journal of Sheep and Goats Sciences, 14(1): 39-52.

GALAL, S. 2007. Farm animal genetic resources in Egypt: factsheet. Egyptian Journal of Animal Production, 44(1): 1-23.

GHAZY, A., MOKHTAR, S., EID, M., AMIN, A., ELZAREI, M., KIZAKI, K. and HASHIZUME, K. 2013. Genetic diversity and distances of three Egyptian local sheep breeds using microsatellite markers. Research in Zoology, 3(1): 1-9.

GUASMI, F., ELFALLEH, W., HANNACHI, H., FERES, K., TOUIL, L., MARZOUGUI, N. and FERCHICHI, A. 2012. The use of ISSR and RAPD markers for genetic diversity among south Tunisian barley. International Scholarly Research Network Agronomy, 2012: 952196.

HAIDER, N., NABULSI, I. and MIRALI, N. 2012. Phylogenetic relationships among date palm (Phoenix dactylifera L.) cultivars in Syria using RAPD and ISSR markers. Journal of Plant Biology Research, 1(2): $12-24$.

JACCARD, P. 1908. Nouvelles recherches sur la distribution florale. Bull. Soc. Vaud. Sci. Nat., 44(163): 223-270.

MAHFOUZ, E. R., OTHMAN, O. E., EL NAHAS, S. M. and EL BARODY, M. A. 2008. Genetic variation between some Egyptian sheep breeds using RAPD-PCR. Research Journal of Cell and Molecular Biology, 2(2): 46-52.

MOHAMMADABADI, M. R., ESFANDYARPOOR, E. and MOUSAPOUR, A. 2017. Using inter simple sequence repeat multi-loci markers for studying genetic diversity in Kermani sheep. Journal of Research and Development, 5(2): 154.

MOUSA, E., OSMAN, M. A. and EL-SAIED, U. 2006. Genetic parameters for body weight of Egyptain Farafra lambs with random regression model. Egyptian Journal of Animal Production, 43: 57-69.

OTHMAN, O. E., PARISET, L., BALABEL, E. A. and MARIOTI, M. 2015. Genetic characterization of Egyptian and Italian sheep breeds using mitochondrial DNA. Journal of Genetic Engineering and Biotechnology, 13(1): 79-86.

POWELL, W., MORGANTE, M., ANDRE, C., HANAFEY, M., VOGEL, J., TINGEY, S. et al. 1996. The comparison of RFLP, RAPD, AFLP and SSR (microsatellite) markers for germplasm analysis. Molecular Breeding, 2(3): 225-238.

PRASAD, B., BABAR, M. A., XU, X. Y., BAI, G. H. and KLATT, A. R. 2009. Genetic diversity in the US hard red winter wheat cultivars as revealed by microsatellite markers. Crop and Pasture Science, 60(1): 16-24.

PREVOST, A. and WILKINSON, M. 1999. A new system of comparing PCR primers applied to ISSR fingerprinting of potato cultivars. Theoretical and applied Genetics, 98(1): 107-112.

RUSHDI, H. E. 2018. Microsatellite-based genetic diversity among Egyptian sheep breeds. Journal of Animal and Poultry Production, 9(4): 219-226.

TONK, F. A., TOSUN, M., ILKER, E., ISTIPLILER, D. and TATAR, O. 2014. Evaluation and comparison of ISSR and RAPD markers for assessment of genetic diversity in triticale genotypes. Bulgarian Journal of Agricultural Science, 20(6): 1413-1420. 
WILliAMS, J. G. K., KUBELIK, A. R., LIVAK, K. J., RAFALSKI, J. A. and TINGEY, S. V. 1990. DNA polymorphism amplified by arbitrary primers are useful as genetic markers. Nucleic acids research, 18(22): 6531-6535.

ZAMANI, P., AKHONDI, M. and MOHAMMADABADI, M. 2015. Associations of Inter-Simple Sequence Repeat loci with predicted breeding values of body weight in sheep. Small Ruminant Research, 132(3): 123-127.

ZIETKIEWICZ, E., RAFALSKI, A. and LABUDA, D. 1994. Genome fingerprinting by simple sequence repeat (SSR)-anchored polymerase chain reaction amplification. Genomics, 20(2): 176-183.

Contact information

Talaat Bashandy: talat55@yahoo.com 